\title{
Effect of season of birth and of hemicastration on the histology of the testis of 6-month-old lambs
}

\author{
Marie-Thérèse Hochereau-de Reviers, R. B. Land*, Christine Perreau and \\ R. Thompson $\dagger$
}

I.N.R.A. Station de Physiologie de la Reproduction, 37380 Nouzilly, France, *A.R.C. Animal Breeding Research Organisation, Field Laboratory, Roslin, Midlothian EH25 9PS, and $\dagger$ A.R.C. Unit of Statistics, West Mains Road, Edinburgh EH9 3JZ, U.K.

\begin{abstract}
Summary. Season but not hemicastration affected the cellular composition of the testis. Despite similar weight, the testicular histology differed markedly with season of birth. The number of Leydig cells and of Sertoli cells was greater in summer- than in winterborn lambs by factors of 2 and 1.5 respectively. Similarly the number of spermatogonia and their rate of production increased substantially in summer-born lambs. The rate of spermatid production was affected by both hemicastration and season. Season of birth exerted more modifications to testicular histology than did hemicastration.
\end{abstract}

\section{Introduction}

Season of birth affects testicular growth in ram lambs (Courot, de Reviers \& Pelletier, 1975), the testes of lambs born in the autumn growing more rapidly than those of lambs born in the spring. This effect could be associated with variation in the sensitivity to the negative feedback effects of gonadal hormones on gonadotrophin release as demonstrated for females (Legan, Karsch \& Foster, 1977). However, the assessment of the effects of variation in negative feedback by measurement of the response to hemicastration in two different seasons indicated that it was not a contributory factor for at least those seasons (Land, Drury \& Fordyce, 1979). Alternatively, the relative proportion of particular cell types could be affected by the season of birth and growth. The aim of the present work was to study the populations of cells in the testis remaining after hemicastration and in the normal testis of lambs born in winter or summer.

\section{Materials and Methods}

Finn-Dorset lambs, 17 born in winter 1977 (31 December 1976 to 20 January 1977) and 21 born in summer 1977 ( 2 July to 12 August 1977) were studied. In both seasons, the lambs were born and reared indoors, and were weaned at 8 weeks. They were offered a creep feed $(15 \%$ crude protein, $12.6 \mathrm{MJ} / \mathrm{kg}$ dry matter) ad libitum from 6 weeks, and hay ad libitum from 8 weeks, up to 19 weeks of age. Eight of the winter-born and 10 of the summer-born lambs served as controls; the remainder, chosen at random, were hemicastrated at 12 weeks \pm 3 days of age. The animals were killed at 6 months of age and in each group one testis of each lamb was fixed in Bouin's solution.

Histological analysis of intertubular and tubular tissue was performed as previously described (Hochereau-de Reviers, Loir \& Pelletier, 1976a; Hochereau-de Reviers et al., 1979). The relative 
volumes of intertubular tissue and seminiferous tubules were determined with a 25 -point ocular integrator (Hennig, 1957) on 20 fields for each testis. The relative proportion of Leydig cells in the intertubular tissue was determined by the same method on 20 fields of intertubular tissue for each testis. The total volumes of intertubular tissue, Leydig cells and tubular tissue were then calculated from the testis volume and the relative volume of each element respectively. The diameter of the seminiferous tubules was measured with an ocular micrometer on 20 cross-sections of tubules per testis.

The cross-sectional areas of the cytoplasm and nuclei of Leydig cells and that of the nuclei of Sertoli cells were estimated with a microscopic planimeter (ASM Leitz) on 20 cells per animal. The total number of Leydig cells per testis was calculated from the estimation of Leydig cell volume.

The Sertoli cell and type $A_{0}$ and $A_{1}$ spermatogonia (Hochereau-de Reviers, Ortavant \& Courot, $1976 \mathrm{~b})$ of each animal were counted in 10 cross-sections $(10 \mu \mathrm{m}$ thick) at stage 8 of the classification of Ortavant (1959). The true numbers of the spermatogenic cells per cross-section were calculated by the formulae of Abercrombie (1946) as modified by Ortavant (1959). The total length of the seminiferous tubules per testis was calculated from the testis weight, the relative volume of seminiferous tubules and the cross-sectional area of seminiferous tubules (Attal \& Courot, 1963). The total area of the walls of the seminiferous tubules was calculated from the total length of seminiferous tubules and the mean cross-sectional tubular diameter. The total numbers of Sertoli cells and $A_{0}$ and $A_{1}$ spermatogonia per testis were determined as described by Attal \& Courot (1963).

The daily productions of $A_{1}$ spermatogonia, leptotene primary spermatocytes and round spermatids were calculated by the method of Amann (1970). The yields of spermatogonial multiplication and of meiotic prophase were calculated from the ratio of the true number of leptotene primary spermatocytes to $A_{1}$ spermatogonia and that of round spermatids to leptotene primary spermatocytes respectively.

Least squares techniques were used to estimate the effects of season and hemicastration and of the interaction between them. The correlations amongst variables were calculated within hemicastration-season groups as well as independently of treatment.

\section{Results}

Testis weight. Testicular weight did not differ significantly between winter- and summer-born animals but was significantly higher in hemicastrated than in intact lambs (Table $1, P<0.001$ ). At 6 months of age, the weight of the testes was greater in summer- than in winter-born hemicastrated lambs, but the difference was not statistically significant.

Intertubular tissue. There was no significant effect of season of birth or of hemicastration on development of intertubular tissue (Table 1). The total volume of Leydig cells per testis was significantly higher in summer-born animals $(P<0.001)$ but hemicastration had no further effect.

The mean cross-sectional area of Leydig cells was also affected by season; it was significantly less in summer-born animals $(P<0.05)$. Variations in the mean cross-sectional area of Leydig cell nuclei paralleled those of the whole cell. The total number of Leydig cells per testis was significantly higher in summer-born than in winter-born animals (Table 1).

Seminiferous tubules and Sertoli cells. The mean seminiferous tubule diameter (Table 1) was significantly increased by hemicastration $(P<0.05)$ and was higher than in summer-born animals $(P<0.001)$.

The total length of seminiferous tubules was greater in summer- than in winter-born animals $(P<0.001)$. The surface area of tubular wall was increased by hemicastration $(P<0.05)$ and was greater in summer- than in winter-born animals $(P<0.01)$.

The total number of Sertoli cells per testis was greater in summer-than in winter-born animals $(P<0.001)$. 
Table 1. Testicular weight and characteristics of 6-month-old winter- and summer-born hemicastrated and control lambs

\begin{tabular}{|c|c|c|c|c|c|c|c|}
\hline \multirow[b]{2}{*}{ Trait } & \multirow[b]{2}{*}{$\begin{array}{l}\text { Overall } \\
\text { mean }\end{array}$} & \multicolumn{3}{|c|}{ Season of birth* } & \multicolumn{3}{|c|}{ Treatment* } \\
\hline & & Summer & Winter & $P$ & $\begin{array}{l}\text { Hemi- } \\
\text { castration }\end{array}$ & Control & $P$ \\
\hline Weight $(\mathrm{g})$ & 168 & - & - & $>0.05$ & 186 & 147 & $<0.001$ \\
\hline Intertubular volume $\left(\mathrm{cm}^{3}\right)$ & $32 \cdot 6$ & - & - & $>0.05$ & - & - & $>0.05$ \\
\hline Total volume of Leydig cells $\left(\mathrm{cm}^{3}\right)$ & $6 \cdot 4$ & $8 \cdot 41$ & $4 \cdot 18$ & $<0.001$ & - & - & $>0.05$ \\
\hline $\begin{array}{l}\text { Cross-sectional area of Leydig cells } \\
\left(\mu \mathrm{m}^{2}\right)\end{array}$ & $80 \cdot 3$ & $76 \cdot 2$ & $84 \cdot 6$ & $<0.05$ & - & - & $>0.05$ \\
\hline $\begin{array}{l}\text { Cross-sectional area of nuclei of Leydig } \\
\text { cells }\left(\mu \mathrm{m}^{2}\right)\end{array}$ & $26 \cdot 0$ & $25 \cdot 0$ & $27 \cdot 2$ & $<0.05$ & - & - & $>0.05$ \\
\hline Total no. Leydig cells/testis $\left(\times 10^{6}\right)$ & 1210 & 1663 & 731 & $<0.001$ & -- & - & $>0.05$ \\
\hline Diameter of seminiferous tubule $(\mu \mathrm{m})$ & 235 & 218 & 253 & $<0.001$ & 242 & 227 & $<0.05$ \\
\hline $\begin{array}{l}\text { Length of seminiferous tubules/testis } \\
(\mathrm{m})\end{array}$ & 2124 & 2496 & 1731 & $<0.001$ & - & - & $>0.05$ \\
\hline Area of tubule wall/testis $\left(\mathrm{cm}^{2}\right)$ & 158 & 177 & 137 & $<0.01$ & 171 & 142 & $<0.05$ \\
\hline Sertoli cells/testis $\left(\times 10^{9}\right)$ & $4 \cdot 02$ & $4 \cdot 81$ & $3 \cdot 19$ & $<0.001$ & - & - & $>0.05$ \\
\hline $\begin{array}{l}\text { Cross-sectional area of Sertoli cell nuclei } \\
\left(\mu \mathrm{m}^{2}\right)\end{array}$ & $60 \cdot 0$ & - & - & $>0.05$ & - & - & $>0.05$ \\
\hline No. of $A_{0}$ spermatogonia/testis $\times 10^{6}$ & $80 \cdot 3$ & 98 & 62 & $<0.07$ & - & - & $>0.05$ \\
\hline $\begin{array}{l}\text { Daily production of } A_{1} \text { spermatogonia/ } \\
\text { testis } \times 10^{6}\end{array}$ & $2 \cdot 16$ & $2 \cdot 63$ & $1 \cdot 67$ & $<0.01$ & - & - & $>0.05$ \\
\hline $\begin{array}{l}\text { Daily production of leptotene } 1^{\circ} \\
\text { spermatocytes/testis } \times 10^{6}\end{array}$ & $78 \cdot 0$ & $89 \cdot 7$ & $65 \cdot 5$ & $<0.01$ & $86 \cdot 1$ & $68 \cdot 2$ & $<0.05$ \\
\hline $\begin{array}{l}\text { Daily production of round spermatids/ } \\
\text { testis } \times 10^{6}\end{array}$ & 212 & 253 & 169 & $<0.001$ & 235 & 186 & $<0.05$ \\
\hline $\begin{array}{l}\text { Yield of } 1^{\circ} \text { spermatocytes/ } \\
A_{1} \text { spermatogonium }(\%)\end{array}$ & $41 \cdot 3$ & - & - & $>0.05$ & - & - & $>0.05$ \\
\hline $\begin{array}{l}\text { Yield of meiotic prophase (spermatids/ } \\
\text { leptotene, } \% \text { ) }\end{array}$ & $2 \cdot 76$ & - & - & $>0.05$ & - & - & $>0.05$ \\
\hline
\end{tabular}

* Subclass means are not given for effects which are not statistically significant.

The area of the cross-section of Sertoli cell nuclei was not affected by season of birth or by hemicastration.

Spermatogenesis. The total number of $\mathrm{A}_{0}$ reserve cells per testis was very variable so that even the $50 \%$ greater number present in summer- than in winter-born lambs was not statistically significant (Table 1). The daily production of $A_{1}$ spermatogonia was greater in summer- than winter-born animals $(P<0.01)$. The daily production of leptotene primary spermatocytes was increased by hemicastration $(P<0.05)$ and greater in summer-born animals $(P<0.01)$.

The daily production of round spermatids per testis was significantly affected by season $(P<$ $0 \cdot 001)$ and by hemicastration $(P<0.05)$.

The yield of spermatogonial multiplication varied considerably with season and hemicastration but, as with the number of reserve stem cells, the within-group variation was high and the effects not statistically significant. The size of the effects was such that the summer-born control lambs had only half the yield $(27 \%)$ of the other three groups $(45-47 \%)$. The yield of meiotic prophase did not vary significantly. With similar yields from meiosis, the low efficiency of spermatogonial multiplication was reflected in lower overall yields of round spermatids per $A_{1}$ spermatogonium in the summer-born control lambs than in the other three groups, but again this effect was not statistically significant.

Interrelationships. The within-group correlations showed relationships which were independent of the effects of treatment (Table 2).

Variations in testicular weight were equally associated with variation in the intertubular 


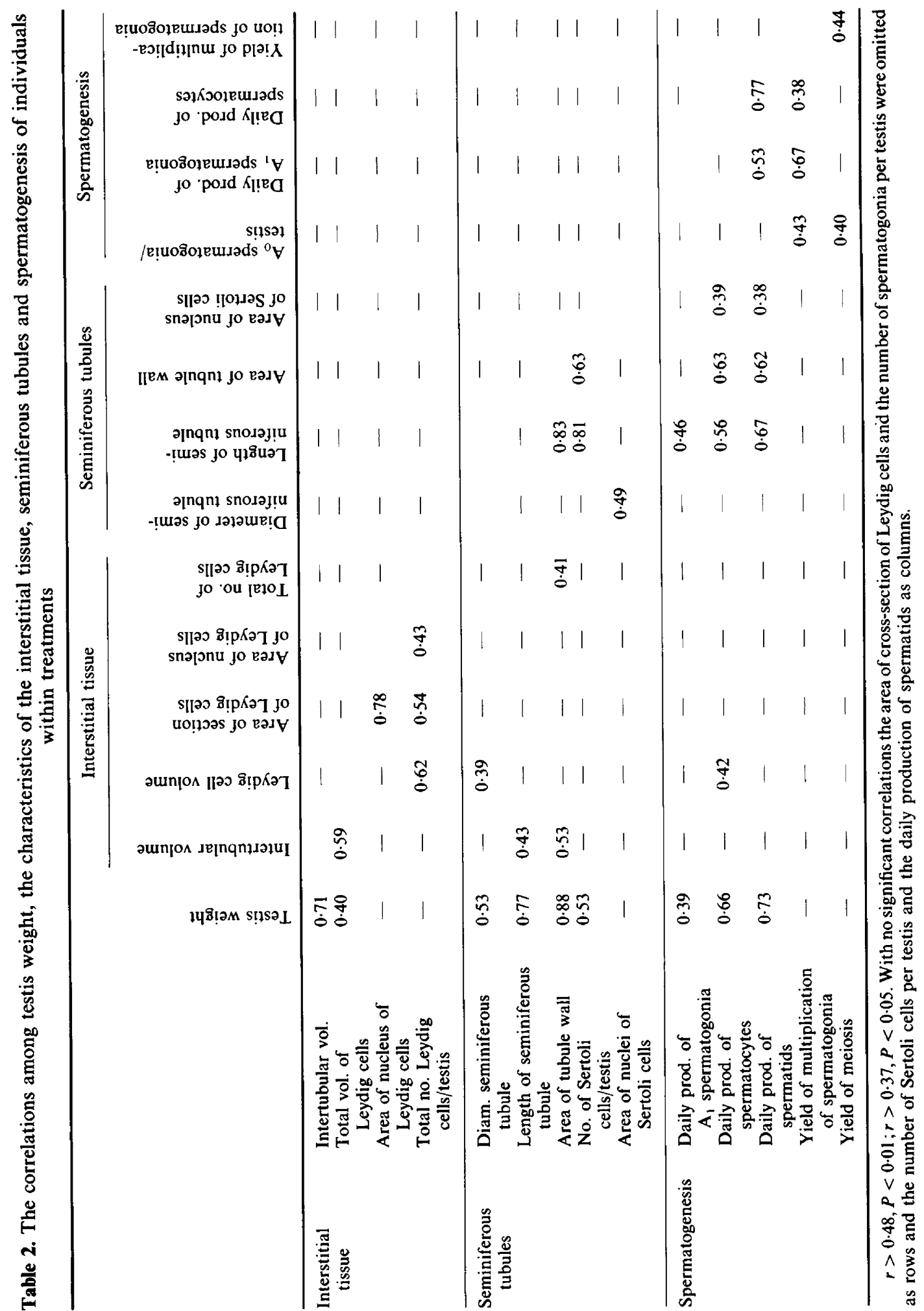


volume and the length of the seminiferous tubules. The correlations between testicular weight and the production of spermatogonia, spermatocytes and spermatids are as high as those between the length or surface area of the tubular wall of the seminiferous tubule and these three components of spermatogenesis, indicating that testicular weight is an equally good predictor.

The only significant correlation between a component of the interstitial tissue and the characteristics of spermatogenesis was that of 0.42 between the total volume of Leydig cells and the daily production of spermatocytes.

The area of the nucleus of the Sertoli cells, but not the number of Sertoli cells, was related to the daily rate of production of spermatocytes and spermatids. Neither the size of the nucleus nor the number of Sertoli cells was related to either the size or number of Leydig cells.

\section{Discussion}

The weight of the testes of the lambs in this study was not affected by the season of birth, as reported earlier for testis diameter (Land et al., 1979). With a constant age of sampling, however, season of birth is fully confounded with season of sampling so that the effects of birth on testis size reported by Skinner \& Rowson (1968) for Suffolk $\times$ Welsh Mountain lambs could have been counterbalanced by effects of season of measurement.

Despite similar gross size, the testicular histology differed markedly in the lambs born in the two seasons. The number of Leydig cells per testis was approximately twice as great in the summerborn lambs, so that, even with a small cell volume difference in the opposite direction, the total volume of Leydig cells was approximately twice as great in the summer-born lambs. Equally, as reported by de Reviers et al. (1980), more Sertoli cells were observed in the testes of summer-born lambs although the difference was 1.5- rather than 2-fold. Of these differences, the greater number of Sertoli cells in summer-born lambs has been reported earlier by de Reviers et al. (1980).

Sertoli cell division ceases before puberty in the ram (Courot, 1971), at around 40 days of age in Romanov $\times$ Ile-de-France crossbred lambs (M. T. Hochereau-de Reviers, C. Monet-Kuntz, C. Perreau \& M. Courot, unpublished data). Also, the total number of Sertoli cells per testis is similar at birth in lambs even in different seasons (M. T. Hochereau de Reviers \& C. Perreau, unpublished observations). The present differences in Sertoli cell populations may be deduced to have arisen from an effect of season of rearing on the rate of Sertoli cell division during the first 2 months of the life of the ram.

In contrast to the Sertoli cells, it is known that the rate of division of Leydig cells is low until 2 months of age when it then increases dramatically while, as with the Sertoli cells, the number present at birth is not affected by season (M. T. Hochereau-de-Reviers \& C. Perreau, unpublished observations). It may therefore be argued that the present difference in numbers arose during the phase of rapid testicular growth after 2 months of age. Again, the surface area of the basement membrane was greater in the summer-born lambs but this could have been an effect of the season of sampling.

The stock of reserve stem cells ( $A_{0}$ spermatogonia) was not affected by the season of birth, confirming the conclusion of Hochereau-de Reviers (1981), from study of rams born in different seasons but sampled in the breeding season, that the number of $\mathrm{A}_{0}$ stem cells is independent of time of birth. However, the rate of differentiation of these cells is affected by season; the greater rate of production of $A_{1}$ spermatogonia could be related to the greater number of Sertoli cells as postulated by de Reviers et al. (1980) for Ile-de-France rams. The possibility of such an association is supported by a correlation of 0.35 between the two characteristics within the present groups, even though this was not statistically significant $(P=0.05$ for $r=0.37)$.

By contrast to these effects of season, none of the early stages of spermatogenesis was affected by hemicastration. Both hemicastration and season, however, affected the later stages of spermatogenesis. This differentiation of the effects of season and hemicastration could arise from 
either of or a combination of two sources; the early stages of spermatogenesis could be determined before 12 weeks of age and hence be effects of birth, or the effects of season on the hormonal equilibria controlling spermatogenesis must differ from the perturbation due to hemicastration. The experiments presented above indicate that the number of stem cells at birth is a characteristic of the animal, independent of season and that the multiplication of these stem cells to $A_{1}$ spermatogonia is affected by the season through an effect on the number of Sertoli cells. Once the number of Sertoli cells is determined, any further modification of the rate of spermatogenesis can be influenced acutely by modification of the equilibria between pituitary trophic hormones and feedback hormones from the testis.

Courot (1970) showed in hypophysectomized lambs that mitosis of the precursors of Sertoli cells were under LH + FSH control, FSH alone being unable to maintain this cell population. Season is known to affect the frequency of LH pulses of young lambs (Lafortune et al., 1982), and this led de Reviers $e t$ al. (1980) to argue that LH pulse frequency of the young lamb partly controls the number of Sertoli cells of the adult. In the present experiment, all the effects of season on the rate of production of spermatids ( $50 \%$ ), as observed previously by Ortavant (1959), Hochereau-de Reviers et al. (1976b) and Schanbacher \& Ford (1979), could have arisen from the difference in the daily rate of production of $A_{1}$ spermatogonia $(57 \%)$, whereas the effect of hemicastration on the daily production of spermatids ( $26 \%$ ) arose entirely from effects on the differentiation of similar numbers of $A_{1}$ spermatogonia.

Hemicastration showed that spermatogenesis can be increased in individual testes of summerborn lambs, thus indicating that the limit to spermatogenesis in the intact lamb is under systemic control. Changes in the concentration of FSH have been implicated in the increased rate of growth of the testis after hemicastration (Walton, Evins, Hillard \& Waites, 1980; de Reviers et al., 1980; Land, Baird \& Carr, 1981) and passive immunization against oestrogens or oestrogen supplementation (Jenkins \& Waites, 1983). Although the increase in the concentration of FSH was about 1.5 times in both studies, the variation amongst animals within groups was such that the effect was not statistically significant.

The season in which the lamb is reared has a marked effect on the establishment of interstitial cells and those of spermatogenesis. The histological components of the increased growth of the testis were therefore the same at both times of the year. This indicates that the systemic feedback equilibria controlling spermatogenesis were not affected by season.

We thank M. Fordyce for help with surgery.

\section{References}

Abercrombie, M. (1946) Estimation of nuclei populations from microtome sections. Anat. Rec. 94, 238-248.

Amann, R. (1970) Sperm production rates in the testis. In The Testis, Vol. 1, pp. 433-482. Eds A. D. Johnson, W. R. Gomes \& N. L. VanDemark. Academic Press, New York.

Attal, J. \& Courot, M. (1963) Développement testiculaire et établissement de la spermatogenèse chez le taureau. Annls Biol. anim. Biochim. Biophys. 3, 219241.

Courot, M. (1971) Etablissement de la spermatogenèse chez l'agneau (Ovis aries). Etude expérimentale de son contrôle gonadotrope: importance de la lignée Sertolienne. Thèse D. es Sci., Paris.

Courot, M., de Reviers, M.M. \& Pelletier, J. (1975) Variations in pituitary and blood LH during puberty in the male lamb. Relation to time of birth. Annls Biol. anim. Biochim. Biophys. 15, 509-516. de Reviers, M., Hochereau-de Reviers, M.T., Blanc, M.R., Brillard, J.P., Courot, M. \& Pelletier, J. (1980) Control of Sertoli and germ cell populations in the cock and sheep testes. Reprod. Nut. Develop. 20, 241249.

Hennig, A. (1957) Das Problem des kernmessung Eine Zusammenfassung und Eirwerterung des mikroskopischen Messtechnik. Mikroskopie 12, 174-203.

Hochereau-de Reviers, M.T. (1981) Control of spermatogonial multiplication. In Reproductive Processes and Contraception, pp. 307-331. Ed. K. W. McKerns. Plenum Press, New York.

Hochereau-de Reviers, M.T., Loir, M. \& Pelletier, J. (1976a) Seasonal variations in the response of the testis and LH levels to hemicastration of adult rams. J. Reprod. Fert. 46, 203-209.

Hochereau-de Reviers, M.T., Ortavant, R. \& Courot, M. (1976b) Type A spermatogonia in the ram. In 
Progress in Reproductive Biology: Sperm Action, Vol. 1, pp. 13-19. Eds. P. O. Hubinont \& M. L'Hermite. Karger, Basle.

Hochereau-de Reviers, M.T., Blanc, M.R., Cahoreau, C., Courot, C., Dacheux, J.L. \& Pisselet, C. (1979) Histological testicular parameters in bilateral cryptorchid adult rams. Annls Biol. anim. Biochim. Biophys. 19, 1141-1146.

Jenkins, N. \& Waites, G.M.H. (1983) Effects of hemicastration at various ages and of oestradiol-17 $\beta$ on plasma concentrations of gonadotrophins and androgens, testicular growth and interstitial cell responses in prepubertal lambs. J. Reprod. Fert. 68, 325-334.

Lafortune, E., Hochereau-de Reviers, M.T., Perreau, C., Blanc, M.R., Orgeur, P. \& Pelletier, J. (1982) Evolutions comparées des teneurs plasmatiques de FSH, LH et la testostérone entre la naissance et la puberté chez l'agneau en fonction de la saison et de la race. Annls Endocr., Paris 43, 124.

Land, R.B., Drury, D.J. \& Fordyce, M. (1979) Season of birth and the response to hemicastration in lambs. Anim. Prod. 29, 379-384.

Land, R.B., Baird, D.T. \& Carr, W.R. (1981) Increased testicular growth of Tasmanian Merino ram lambs treated with antisera to oestrogens. J. Reprod. Fert. 62, 151-158.

Legan, S.J., Karsch, F.J. \& Foster, D.L. (1977) The endocrine control of seasonal reproductive function in the ewe: a marked change in response to the negative feedback action of estradiol on luteinizing hormone secretion. Endocrinology 101, 818-824.

Ortavant, R. (1959) Déroulement et durée du cycle spermatogénétique chez le bélier. Annls Zootech. 8, 183-244, 271-321.

Schanbacher, B.D. \& Ford J.J. (1979) Photoperiodic regulation of ovine spermatogenesis: relationship to serum hormones. Biol. Reprod. 20, 719-726.

Skinner, J.D. \& Rowson, L.E.A. (1968) Puberty in Suffolk and crossbred rams. J. Reprod. Fert. 16, 479488.

Walton, J.S., Evins, J.D., Hillard, M.A. \& Waites, G.M.H. (1980) Follicle stimulating hormone release in hemicastrated prepubertal rams and its relationship to testicular development. J. Endocr. 84, 141152.

Received 5 May 1983 